\title{
A Coptic Liturgical Prayer for the Consecration of the Chalice
}

\author{
Anastasia Maravela, Ágnes T. Mihálykó \& Glenn Ø. Wehus*
}

\begin{abstract}
Edition with philological, theological and liturgical commentary of a Coptic prayer preserved on a papyrus from the seventh or eighth century in the collection of the University of Oslo Library. The prayer, which accompanied the consecration of the wine in the chalice in the presence of already consecrated bread, has a coda in Greek signalling the ensuing oral recitation of the Lord's Prayer.
\end{abstract}

Keywords: prayer, consecration, chalice, presanctified, bilingual

DOI 10.1515/apf-2017-0013

The medium brown papyrus sheet, which preserves a Coptic liturgical prayer, has been reconstructed from nine fragments (A-I) while four very small fragments $(\mathrm{J}-\mathrm{M})$ remain unplaced. The upper half has been reconstructed from fragments A-D and the lower half from fragments F-I. The break between the two halves runs right along the middle of 1.9 on the left side of the sheet and along 1. 6 on the right side. Prior to conservation fragments $\mathrm{G}$ and $\mathrm{I}$ were attached onto fragment $\mathrm{F}$ using papyrus strips but

Vorbemerkung: Anastasia Maravela and Ágnes T. Mihálykó are jointly responsible for the introduction, transcription, translation and commentary; Glenn $\varnothing$. Wehus is responsible for the theological parts of the commentary, while the liturgical commentary has been authored by Ágnes T. Mihálykó. The authors thank Lance Jenott, Christian H. Bull, Jens Mangerud, Joanne Stolk, Anne Boud'hors, Alberto Camplani and Karl O. Sandnes for helpful comments on earlier drafts of this edition.

* Kontakt: Anastasia Maravela, Dept. of Philosophy, Classics, History of Art and Ideas, Faculty of Humanities, University of Oslo, NO-0313 Oslo, <anastasia.maravela@ifikk. uio.no>; Ágnes T. Mihálykó Dept. of Philosophy, Classics, History of Art and Ideas, Faculty of Humanities, University of Oslo, NO-0313 Oslo, <a.m.tothne@ifikk.uio.no>; Glenn $\varnothing$. Wehus, The Norwegian School of Theology, Gydas vei 4, NO-0363 Oslo, $<$ Glenn.O.Wehus@mf.no>. 
in the wrong place and upside down. ${ }^{1}$ The loose fragment $\mathrm{H}$ also had remains of papyrus strips on the back; this suggests that it too had once been reattached onto the body of the text but it is unclear where. The unsuccessful repairs were most probably carried out in modern times as they may be observed in some other papyri from the same lot (most notably inv. 1664) as well as in papyri in the Carlsberg collection purchased from the same source at about the same time. In reconstructed state the sheet appears severely damaged in the middle. Nonetheless part of the broken text may be restored in the light of parallels in similar texts (see commentary on 11.4-12).

The text has been penned using medium thick pen and brown ink. It amounts to 2311 ., of which $17 \mathrm{ll}$. cover the front side of the leaf where the writing goes with the fibres, while 6 1l. occupy the upper part of the back side where the writing runs against the fibres. Where it can be established with certainty line length varies between fifty and sixty-seven letters. Calculations of letters broken away are approximate as the lower part of the sheet has suffered some shrinkage. Scanty remains, possibly ends, of nine non-consecutive lines as well as eleven or twelve dots (possibly checkmarks) are visible close to the lower edge of fragment $\mathrm{F}$ back side, at $90^{\circ}$ angle to the Coptic text. The content cannot be determined but the presence of these traces confirms that the sheet was cut from a documentary papyrus, flipped over and turned at $90^{\circ}$ angle to receive the new text (transversa charta). All margins are narrow to scanty (margins, front: upper $0.8 \mathrm{~cm}$, left $1-1.2 \mathrm{~cm}$, right: max. $1 \mathrm{~cm}$; margins, back: upper ca. $1.3 \mathrm{~cm}$, left: torn off, right: $1-1.3 \mathrm{~cm}$ ) except the lower ones (front: $2.2 \mathrm{~cm}$; back: ca. $11 \mathrm{~cm}$ ). The sheet was folded down the middle. The horizontal breaks perhaps also correspond to five folds, one in the middle, two in the upper and two in lower part of the sheet.

The format is that of a single sheet used to read from during service. The somewhat ampler lower margin and the space just above the middle of the left margin coincide with convenient places to hold the sheet at. The half-line left empty at the bottom of the front page also served practical purposes as it allowed time to turn the leaf over while reciting the familiar

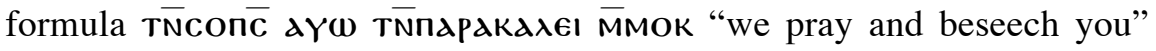
(see also commentary on 1.17).

\footnotetext{
${ }^{1}$ Restoration was carried out under the supervision of Jörg Graf (Universitätsbibliothek, Leipzig) to whom we extend thanks.
} 
The text, which is delimited by an oblique stroke (1. 1) and a cross (1. 23), is a consecratory prayer for (the wine in) the chalice (11. 12-15) in the presence of already consecrated bread (11. 2-3), and was thus pronounced by the priest. It is addressed to God Almighty (1. 1) and has a tripartite articulation by means of the same petitionary formula, $T \bar{N} \operatorname{con} \overline{\mathrm{C}}$

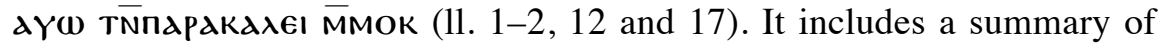
Christ's earthly life (11. 4-12) which culminates in his crucifixion and the pouring forth of blood and water from his pierced side (11. 10-12) which provides the crucial link with the pouring forth of the Holy Spirit over the chalice (11. 3 and 13-14). The last part contains a request for worthy communion (11. 18-20) which leads up to a 'preface' to the Lord's Prayer (11. 20-23) although that prayer, which was recited by the congregation, is not contained on this sheet. The last part of the 'preface' involves code switching from Coptic into Greek (1.23). In a liturgical setting the switch would presumably signal to the people their imminent part, i.e. the oral recitation of the Lord's Prayer.

The prayer presents close similarities in structure and in wording to the consecratory prayer in the Coptic rite of the filling of the chalice. The rite serves to consecrate extra wine if during communion it is found insufficient or corrupted, see İris Habīb Al-Mașrī, "The Rite of the Filling of the Chalice," Bulletin de la Société d'archéologie copte 6 (1940): 77-90. The reference to "already sanctified sacrament" in 11. 2-3 suggests that the prayer may also have connections to the liturgy of the presanctified, see Stefanos Alexopoulos, The Presanctified Liturgy in the Byzantine Rite. A Comparative Analysis of its Origins, Evolution, and Structural Components (Liturgia Condenda 21; Leuven: Peeters, 2009) 113-17. Moreover, a service is attested in which additional bread and/or wine is consecrated after the anaphora in case more is needed for the communion. The earliest mention of this practice is found in two sources from the seventh century Thebaid: in a pastoral epistle, P.Berol. 11346 (edited by Alberto Camplani, "A Pastoral Epistle of the 7th Century Concerning the Eucharist (Pap. Berol. P. 11346)," in Forschung in der Papyrussammlung. Eine Festgabe für das Neue Museum. Ägyptische und Orientalische Papyri und Handschriften des Ägyptischen Museums und Papyrussammlung Berlin, hrsg. von V.M. Lepper, Bd. 1 (Berlin: Akademie-Verlag, 2012), 377-386, which provides instructions in case the priest runs out of bread during the communion, and in the newly discovered Sahidic redaction of Canon 99 
of Basil, which provides instructions for both bread and wine. ${ }^{2}$ The prayer on P.Oslo inv. 1665 could also have served similar purposes. For more details concerning the liturgical Sitz im Leben of this prayer, see the liturgical commentary appended to this edition.

From a theological point of view the prayer reflects a period in the history of the church when the description of the Spirit as co-substantial (ópoov́riov) with the Father and the Son had become accepted after having been hotly debated in the latter part of the fourth century (see comm. on 1.4). The prayer text also emphasizes the will of Christ and the voluntary aspect of his incarnation and suffering, thereby illustrating theological debates which were going on in the wider church in the same period (see com. on 11. 6-7 and 9).

The language is standard and correct Sahidic (with the exception of possible haplography, 11. 9 and 10). Nomina sacra include $\overline{\mathbf{i C}} \mathbf{n \in \overline { x c }}, \overline{\Pi N \alpha}$, the noun and verb for crucifixion (11. 10 and 16) in Coptic and $\overline{\pi \rho \alpha} \varepsilon \pi \overline{\mathrm{ovvl}}$ in Greek. The Greek seems somewhat garbled. Not only is the abbreviation of the adjective messed up. An entire infinitive is missed out (see commentary on 1.23). The scribe uses high point to divide cola and semicolon to signal code switching (1.23). Apart from the usual supralinear strokes (sometimes oblique due to the speed of writing), a shorter stroke is employed to indicate sequences of vowels. Supralinear dots whose function is not entirely clear have been noted on first syllables of certain words (11. 3, 19 and 22).

The scribe has worked with confidence and increasing speed and has produced a piece of writing that gives a neat but informal overall impression. Its major traits are slight letter inclination, modular contrast between letters, pronounced downward traits $(\mathbf{I}, \mathrm{K}, \mathbf{T}, \mathbf{Y}, \mathbf{9}, \boldsymbol{\omega})$ ) and pseudo-ligatures. Characteristic letter forms: small, very rounded $\boldsymbol{\alpha}$ and $\boldsymbol{o}$, both raised above the baseline; narrow $\mathbf{\epsilon}$ and $\mathrm{c}$ with straight left part; $\mathrm{k}$ with pronounced right strokes firmly attached to the left vertical; $\lambda$ with the top of the right stroke projecting over to a "hooked" top; compressed $\mathrm{M}$ with the middle

${ }^{2}$ Thanks to Alberto Camplani for having shared his and Federico Contardi's preliminary transcription of this manuscript. On the manuscript, see Alberto Camplani and Federico Contardi, "The Canons Attributed to Basil of Caesarea. A New Coptic Codex, in Coptic Society, Literature and Religion, from Late Antiquity to Modern Times," in Proceedings of the Tenth International Congress of Coptic Studies, Rome, September 17-22, 2012, and Plenary Reports of the Ninth International Congress of Coptic Studies, Cairo, September 15-19, 2008 (ed. P. Buzi, A. Camplani and F. Contardi (Peeters: Leuven, 2016), 979-992. 
curve at a level with the right and left curves; $\mathrm{N}$ with right leg sometimes raised above the baseline; $\gamma$ with long and straight right arm. The overall impression is close to the letter P.Mon. Epiph. 162 (see photo in P.Mon. Epiph. II, plate VI) which in view of the mention of Epiphanius may be dated in the early seventh century. A documentary letter form right under the last dot in the text written with the fibres on the back of the sheet may be a $\delta$ the upper part of which has a looped form and meets the rounded lower part in the middle. ${ }^{3}$ If the identification is admissible, this letter form would entail dating the liturgical text no earlier than the seventh century. Remarkable are the palaeographical similarities with P.Berl. Sarisch. $7 \rightarrow$ written in a slightly sloping bookhand assigned to the $7^{\text {th }} / 8^{\text {th }}$ century: these include the forms of the letters $\boldsymbol{\lambda}, \mathrm{B}, \boldsymbol{\epsilon}, \mathrm{K}, \mathrm{N}, \mathrm{P}$ and the long descenders of I, K, P, T. The back, P.Berol. 21324 $\downarrow$, contains a Coptic text which presents characteristics, as the large interlinear space and the huge B, that point towards the $8^{\text {th }}$ century. ${ }^{4}$ All these considerations suggest a date in the seventh or eighth century, but nothing weighs decisively in favour of any of the two centuries.

P.Oslo inv. $1665^{5} \rightarrow+\downarrow$

Unknown provenance

ca. $31.2 \times 18 \mathrm{~cm}$

Seventh-eighth century

Fr. A: 14.1 x $4.5 \mathrm{~cm}$; Fr. B: 2.1 x $2.4 \mathrm{~cm}$;

Fr. C: 17 x $6.4 \mathrm{~cm}$; Fr. D: 13.7 x $4.5 \mathrm{~cm}$;

Fr. E: $3.5 \times 1.5 \mathrm{~cm}$; Fr. F: $31 \times 12 \mathrm{~cm}$;

Fr. G: $8.2 \times 3.5 \mathrm{~cm}$; Fr. H: $4.1 \times 2.5 \mathrm{~cm}$;

Fr. I: 3.8 x $3.4 \mathrm{~cm}$; Fr. J: 2.7 x $0.4 \mathrm{~cm}$;

Fr. K: 0.5 x $0.2 \mathrm{~cm}$; Fr. L: $0.3 \times 0.3 \mathrm{~cm}$;

Fr. M: $0.4 \times 0.8 \mathrm{~cm}$

\footnotetext{
${ }^{3}$ The identification is Lajos Berkes'.

${ }^{4}$ Image of both sides are available under $<$ http://ww2.smb.museum/berlpap/ $>$ by searching for inventory number 21324 .

${ }^{5}$ Inv. nos. 1663-1668 were purchased by the Norwegian historian of religion Hermann Ludin Jansen from the Maurice Nahman estate in Cairo in January 1954. Of these, inv. 1666 is a Coptic letter from a female to a monastic by the name apa Hermantinou (edition in preparation by Ágnes T. Mihálykó). Inv. 1668 (Greek) preserves a series of incoherent notes from a homily or other theological text, and has connections with similar pieces of writing in the collection of the Abbey of Montserrat, see Anastasia Maravela and Glenn $\varnothing$. Wehus, "In the Workshop of a Preacher-Scholar? Christian Jottings on an Oslo Parchment," Zeitschift für Papyrologie und Epigraphik 182 (2012): 87-97. Inv. 1667 (edition in preparation by Joanne V. Stolk mentions a topos of Apa Apollo, probably that in Bawit). The documentary texts in the lot seem to come from the Hermopolite.
} 


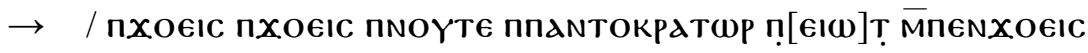

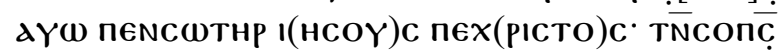

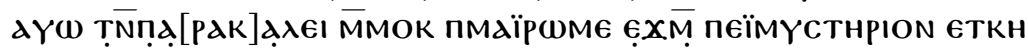
e2paï паї NTaY[TB-]

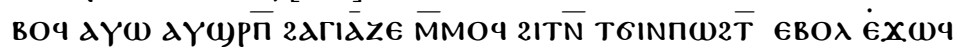
$\bar{M} \Pi \in K \Pi N(\epsilon Y M) d \bar{\epsilon}$ TOYÃa[B]

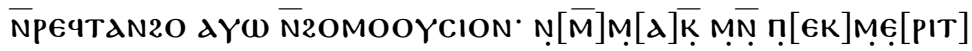

$\bar{N}(1)$ H. I

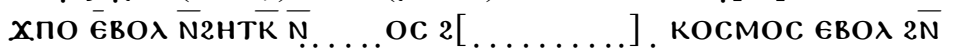
KOYNT ETPEчĀ $[\mathrm{NA}-]$

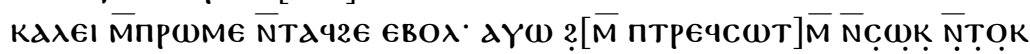

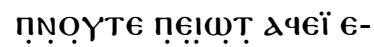

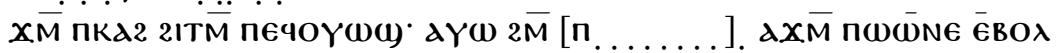
$2 \bar{M} \operatorname{\Pi E} N($ EYM $) d \bar{\epsilon}$ TOY-

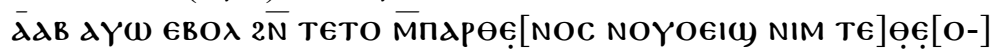

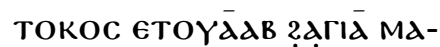

Pla d a

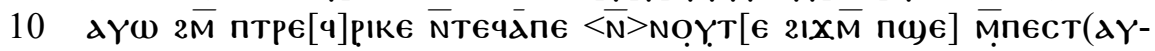

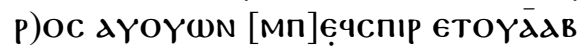

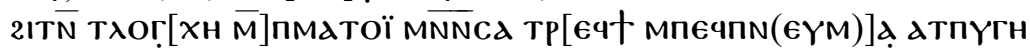

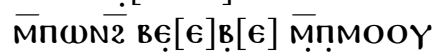

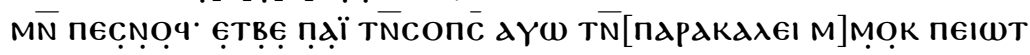

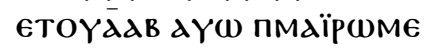

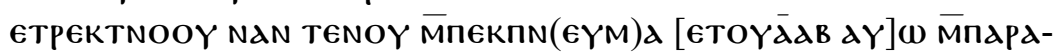

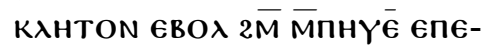

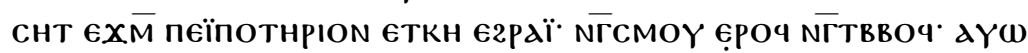

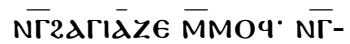

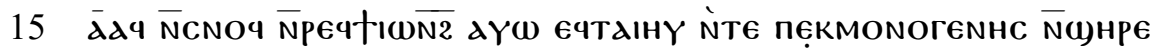
I(HCOY)C nEX(PICTO)C nENXOEIC

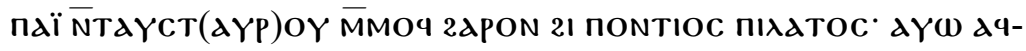

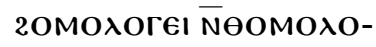

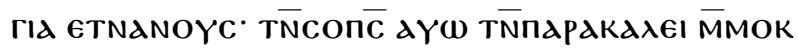

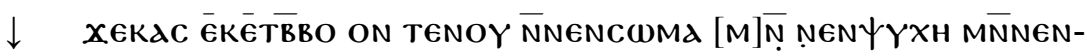

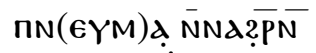

[T] GINC)

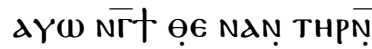

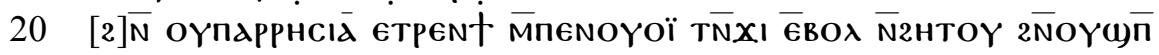

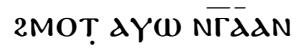




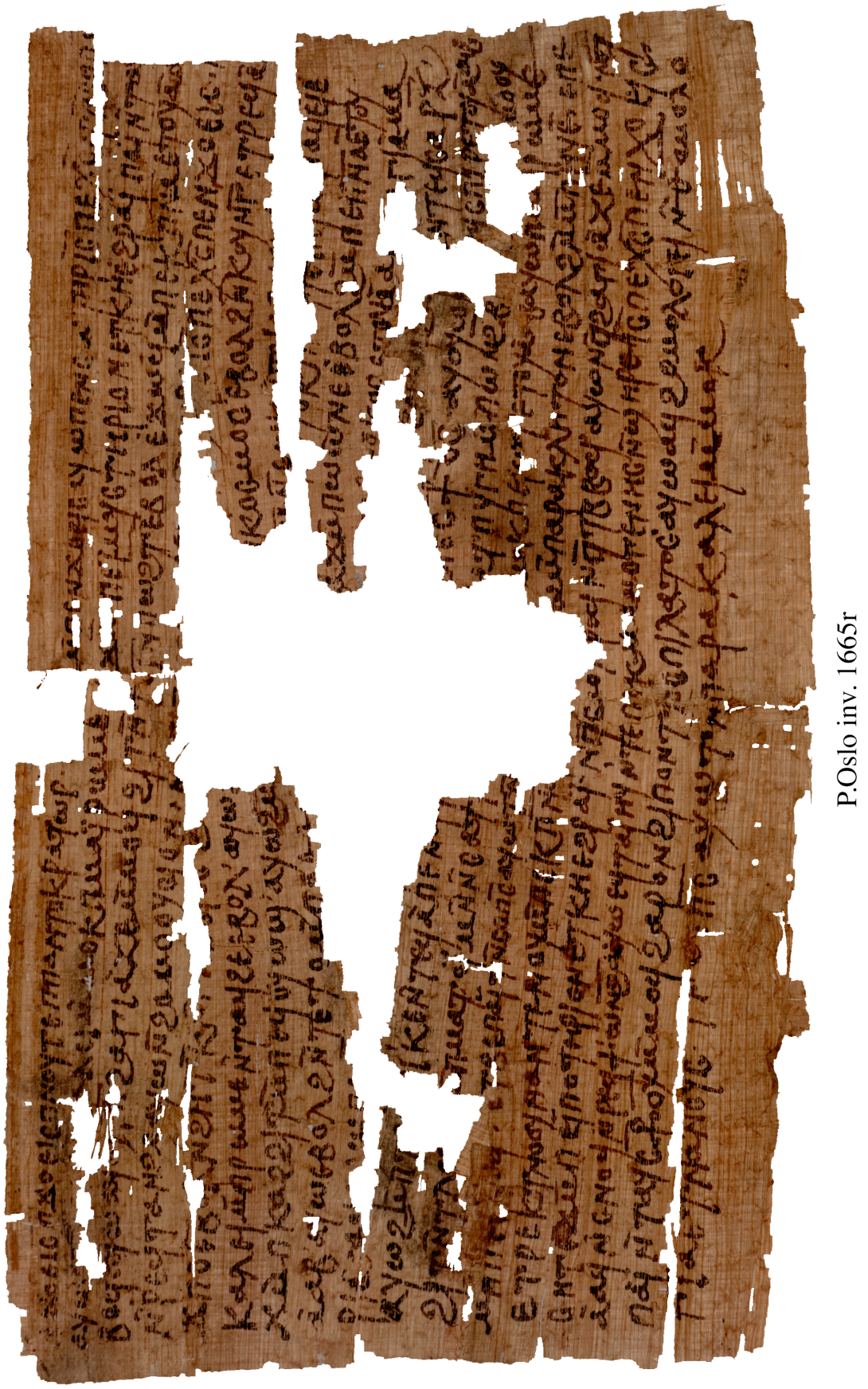




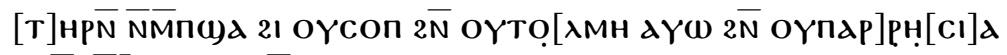
$\bar{N} T \bar{N} \in \Pi I K \lambda \lambda \epsilon ı \bar{M} \Pi \in K-$

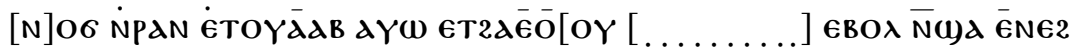
חNOYTE חENEIWT

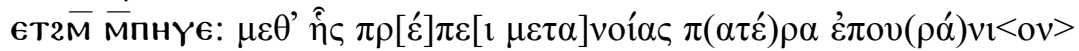

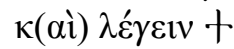

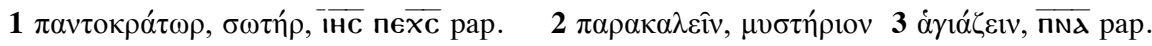

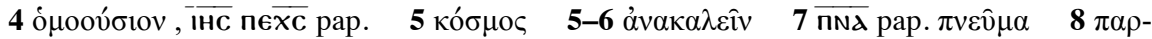

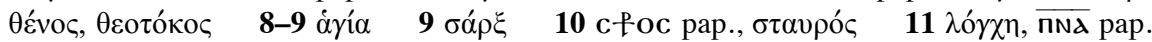

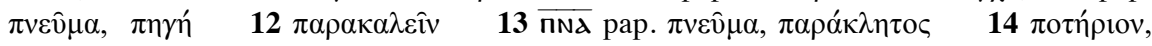

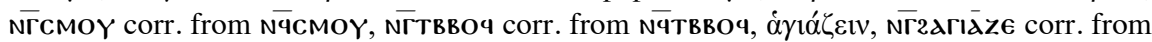

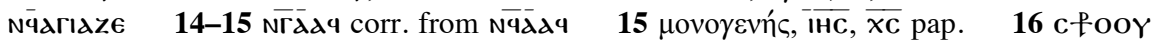

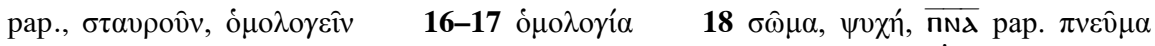

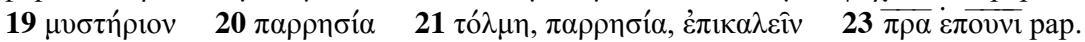

1 Eph $1: 3,1$ Pet 1:3, 2 Cor 1:3 5 John 1:18 10-11 John 19:30 10-12 John 19:34 15-16 1 Tim 6:11-12 181 Thess 5:23 22-23 Matt 6:9

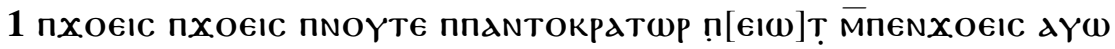
neNCWTHP I(нCOY)C neX(PICTO)C: Typical address of the divine person prayed to in the Coptic liturgy. It is found already in the $4^{\text {th }}$ century e.g. in BKT VI.6 1.62-63, or without 'Father' in P.Monts. Roca 154b.6-7, see Michael S. Zheltov, "The Anaphora and the Thanksgiving Prayer from the Barcelona Papyrus: An Underestimated Testimony to the Anaphoral History in the Fourth Century," VigChr 62 (2008): 484 and 487 (note 64). By the sixth century it acquired such prominence as the appropriate address to God that it was also used in oracular tickets and amulets (Pap.Graec.Mag. P1 and P9 as well as P.Köln VIII 340 and MPER N.S. XVII 10). It is well attested in later liturgical texts, in the White Monastery (e.g. in the anaphora of St. Matthew, see Emmanuel Lanne, Le Grand Euchologe du Monastère Blanc [Turnhout: Brepols, 1958], 356), and in the current liturgy (see The Coptic Liturgy of St. Basil, edited by the Comittee Formed by His Holiness Pope Shenouda III [Cairo: St. John the Beloved Publishing House, 1993], 5). It results from combining two fre-

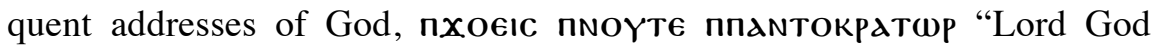

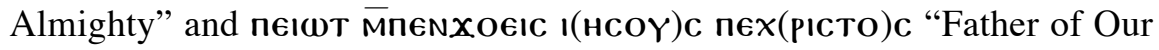
Lord Jesus Christ" (see Achim Budde, Die ägyptische Basilios-Anaphora: Text-Kommentar-Geschichte [Münster: Aschendorff, 2004], 250). The

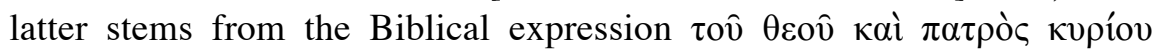

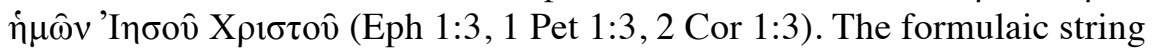




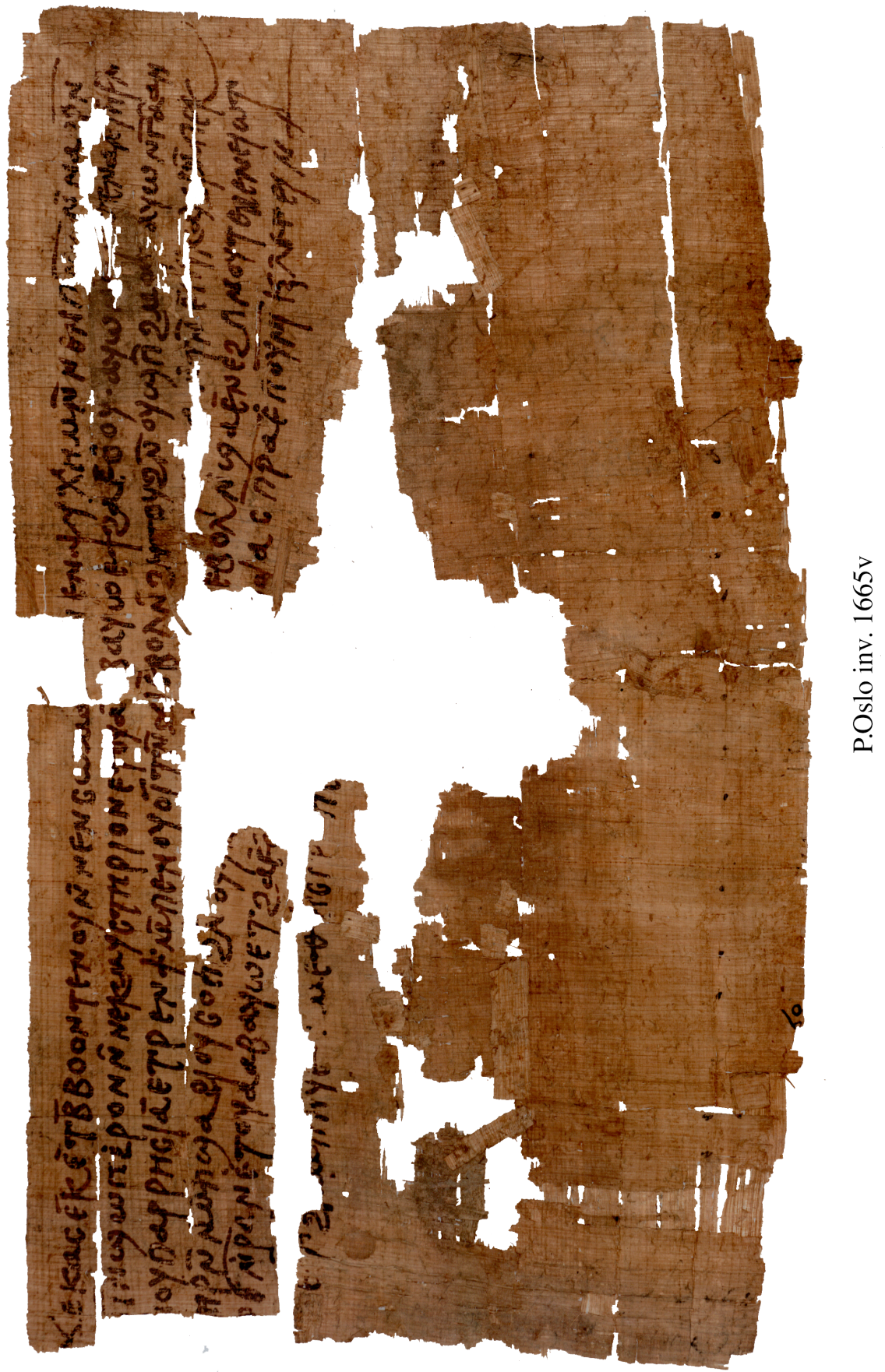


can be expanded by adding various attributes to the name of Christ. Many

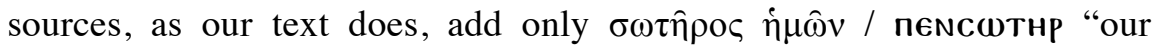
Saviour," already in the fourth century, e.g. in the Euchologium of Sarapion, prayer 17, see Maxwell E. Johnson, The Prayers of Sarapion of Thmuis: A Literary, Liturgical, and Theological Analysis (Rome: Pontifi-

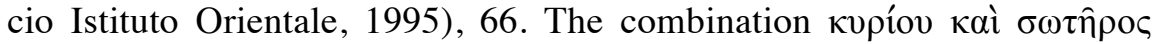

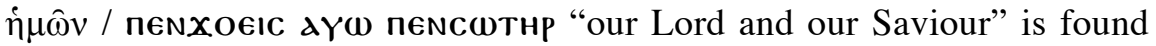
also later, e.g. in O.Petr. Mus. 19 (late fifth cent.), P.Moscow Copt. 95, BM EA 54036.22 (seventh-eighth cent.?, see Hans Quecke, "Ein saïdischer Zeuge der Markusliturgie (Brit. Mus. Nr. 54036)," Orientalia Christiana Periodica 37 [1971]: 44), Q.I. fr. III a/c = Pap.Colon. XXVIII 6 (tenth-eleventh cent.), Q.I. fr. 4/12 = Pap.Colon. XXVIII 8 (tentheleventh cent.,), as well as in Pap.Graec. Mag. P9 (sixth cent.) and Pap.Graec. Mag. P1 (fifth-sixth cent.). The full form with a threefold series of attributes, "our Lord, our God and our Saviour," goes back to at least P.Ryl. III 465.2 (sixth cent.), and becomes standard in the medieval manuscripts. In the prayers stemming from the White Monastery, however, all three versions are found contemporarily (one attribute: see Lanne, Le Grand Euchologe, 366, 372, 392; two attributes: Paris, BnF Copte $129^{20}$ fol. $137 \mathrm{v} .18-20$ and 157 r.12-15; three attributes: Lanne, Le Grand Euchologe, 356).

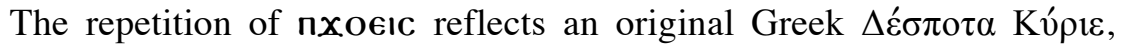
which is translated into Bohairic as фNHB фNOYt, e.g. in the prayer of thanksgiving of the morning rite, see John P. Bute, The Coptic Morning Service for the Lord's Day (London: J. Masters \& Co, 1882), 3 and William F. Macomber, "The Greek Text of the Coptic Mass and of the Anaphoras of Basil and Gregory according to the Kacmarcik Codex," Orientalia Christiana Periodica 43 (1977): 315. As the Sahidic did not have two synonyms for the word, it repeated nxoeıc as here, in BM EA 54036.22 (see Quecke, "Ein saïdischer Zeuge", 44), and in Prague, Or.Inst. MS I p. 1 1. 15 (see Valerie Hažmuková, "Miscellaneous Coptic Prayers I," Archiv Orientalni 8 [1936]: 325).

2-3 пдї NTAY[тв]Івоч аү close parallel in the consecratory prayer of the rite of the filling of the

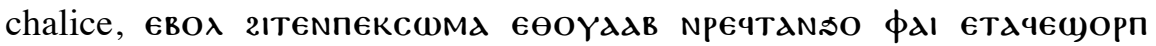

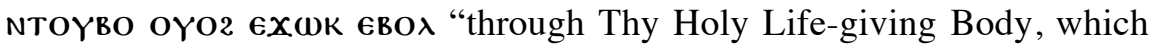
is already sanctified and perfected" (Habīb Al-Mașrī, "The Rite of the Filling," 81-2). A reference to the "previously sanctified piece" ( $\pi \rho \circ \eta-$ 
$\left.\gamma 1 \alpha \sigma \mu \varepsilon^{\prime} v \eta \mu \varepsilon \rho i ́()\right)$ is made in the first consecratory prayer of the chalice in the Nubian texts (Alexopoulos, The Presanctified Liturgy, 116). The pastoral epistle P.Berol. 11346 (the seventh cent., Thebaid), prescribes the call 1. $\mathrm{x}+27$ Td npodridceenta \{Td\} arid TOIC driOIC "the presanctified holies to the holies" ${ }^{\prime 6}$ after the consecration of the additional bread.

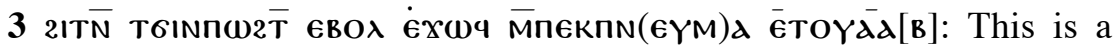
key-expression, picked up by the description of the pouring out of water and blood from Jesus' pierced side (11. 10-12) and the request to send the Spirit to hallow the chalice (11. 12-14).

The phrase has a parallel in the main fraction prayer of the liturgy of St.

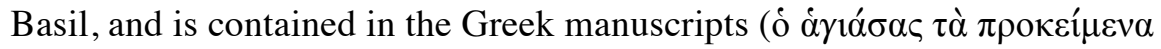

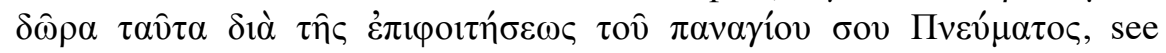

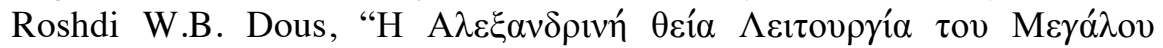

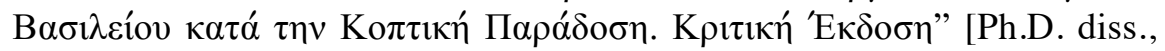
Aristotelian University of Thessaloniki, 1998], 158), and in the Bohairic textus receptus ( $\phi$ H ETAqEPACIAZIN NNAIAOPON NAI ETXH EDPHI 2ITEN

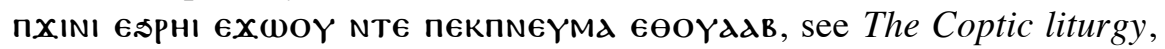
267). The Sahidic version of the same prayer in the Great Euchologium contains only the first half nENTA42|Aríd NNGIAWPON NAí GTKH G2PAi мпєкмто євод, Lanne, Le Grand Euchologe, 388 11. 14-16.

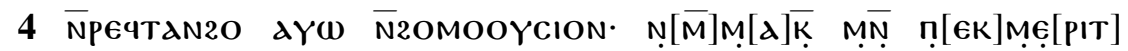

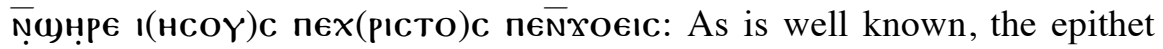
ópoov́oiov ("co-substantial") had a turbulent history in the dogmatic disputes of the early church, starting from its inclusion in the 325 Nicene Creed concerning the relationship of the Son to the Father. For a survey of the history of the term see Pier F. Beatrice, "The Word 'Homoousios' from Hellenism to Christianity," Church History 71.2 (2002): 243-272. From the 360s onward, the related question of the status of the Holy Spirit also came to the fore. In the Nicene Creed the Holy Spirit had been mentioned only by the short phrase "And (we believe) in the Holy Spirit" without any qualifications or elaborations. Starting with Athanasius and his Letters to Serapion, probably from 359 or 360, we find the Church Fathers engaging in polemics with diverse groups over the relationship of the Holy Spirit to the Father and the Son. The most prominent of these groups were the so-called Pneumatomachians ("Spirit-fighters"), also

\footnotetext{
${ }^{6}$ Reconstructed by Á.T. Mihálykó on the basis of a high resolution photo kindly pro-

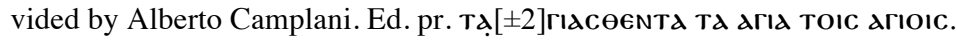


known as the Macedonians, who rejected the divinity of the Spirit and claimed that there was no biblical basis for regarding the Holy Spirit as equal in essence to the Father and the Son. Instead the Spirit was placed in various lower ontological categories, for example as a creature or as intermediate between God and angels, see Richard P.C. Hanson, The Search for the Christian Doctrine of God: The Arian Controversy 318-381 (Edinburgh: T\&T Clark, 1988), 768-769. The two most comprehensive defences of the deity of the Spirit were produced by the two Cappadocians, Basil of Caesarea in On the Holy Spirit (375) and Gregory of Nazianzus in the Fifth Theological Oration (known as Oration 31; from 380). ${ }^{7}$ The issue was debated at the council in Constantinople in 381 , and the assembly decided upon a creedal statement (the Nicene-Constantinopolitan Creed) about the Spirit which was most probably intended as a confirmation of the full deity of the Spirit, but stopping short of using the term ó cal language ( $\sigma \nu \mu \pi \rho \circ \sigma \kappa v v o v ́ \mu \varepsilon v o v ~ \sigma v v \delta o \xi \alpha \zeta o ́ \mu \varepsilon v o v)$. The most probable reason for the assembly not to express their pneumatology in more explicit terms was their wish to tread carefully vis-à-vis the sentiments of their opponents in the hope of reaching a joint statement. ${ }^{8}$ Even though the disputes concerning the nature of the Son and his place within the Trinity continued into the following centuries, as the statements from the later councils show, the debate over the Holy Spirit seems to have settled more quickly, in broad sense being over already by the fifth century (see Joel C. Elowsky, We Believe in the Holy Spirit [Madison, WI: InterVarsity Press, 2009], xxxi).

A Trinitarian use of ópoov́øı̧ is also attested in documentary papyri from the seventh century. Under the reign of the Byzantine emperor Mauritius it was decided (probably sometime around 591) that legal documents were to include an invocation of Christ attached to the regnal for-

\footnotetext{
${ }^{7}$ Gregory had in his Fifth Theological Oration explicitly both called the Spirit God and

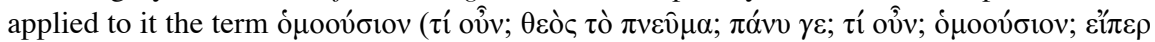

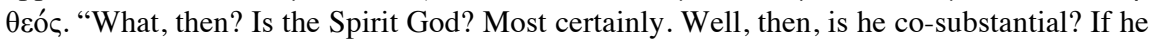
is God, yes," Gregorius Nazianzenus, Oratio 31, 10,1-2 [SC 250, 292,16-17 Gallay]).

${ }^{8}$ See Lewis Ayres, Nicaea and its Legacy. An Approach to Fourth-Century Trinitarian Theology (Oxford: Oxford University Press, 2004), 257-258 although Deno J. Geanakoplos, "The Second Ecumenical Synod of Constantinople (381): Proceedings and Theology of the Holy Spirit," The Greek Orthodox Theological Review 27.4 (1982): 419 has objected that this explanation presupposes that the symbol was discussed before the withdrawal of the Macedonian faction.
} 
mula at the head of the document. The Christological invocation was changed to a Trinitarian one under emperor Phocas in the early seventh century. The latter Trinitarian formula is attested in different variants, listed in Roger S. Bagnall and Klaas A. Worp, Chronological Systems in Byzantine Egypt (2nd edition; Leiden: Brill, 2004), 100-102. Many of

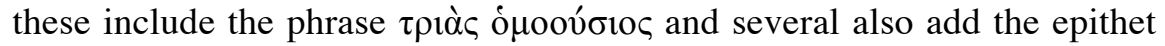
$\zeta \omega 0 \pi$ oó $\varsigma$, as in the present papyrus, a term which ultimately is derived from the Nicene-Constantinopolitan Creed. During the reign of Heraclius a more diverse geographical practice seems to have developed: the earlier Christological invocation comes back into use in Middle Egypt while the Trinitarian invocation continues to be employed in Upper Egypt, see Bagnall and Worp, Chronological Systems, 103-104.

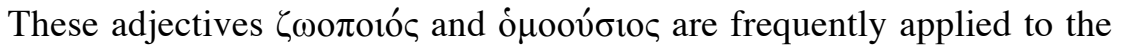
Holy Spirit in medieval Coptic liturgical texts. Thus for example the Bohairic translation of the anaphora of Saint Gregory adds the adjectives NPE4TANbo OYO2 NOMOOYCIOC in five doxologies where it is missing in the Greek redaction (Stephen J. Davis, Coptic Christology in Practice: Incarnation and. Divine Participation in Late Antique and Medieval Egypt [Oxford: Oxford University Press, 2008], 98). The two adjectives are also regular in the doxologies of the Bohairic textus receptus of the liturgy of Saint Basil (see The Coptic Liturgy, 7, 212, 219), as well as in the Greek medieval redaction of the text in the Kacmarcik codex (Macomber, "The Greek Text of the Coptic Mass" 315, 316, 320).

4-5 п![6]|хпо Є̈вол $\overline{\mathbf{N}} 2$ нтк: The expression is contained in the NiceneConstantinopolitan Creed in Sahidic in New York, MLM, M574 p. 148 1. 13, see Hans Quecke, Untersuchungen zum koptischen Stundengebet (Louvain: Université catholique de Louvain, Institut orientaliste, 1970), 436.

\section{Possibly גִọ̣oc.}

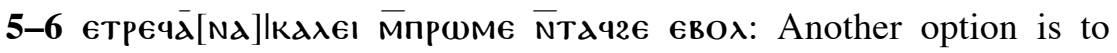
supply the verb $\dot{\alpha} \pi$ oк $\alpha \lambda \varepsilon i v$, which also has the meaning "call back from exile," see $L S J$ s.v. $\dot{\alpha} \pi \circ \kappa \alpha \lambda \dot{\varepsilon} \omega$ I.1. But $\dot{\alpha} v \alpha \kappa \alpha \lambda \varepsilon i ̂ \sigma \theta \alpha$ has a few parallels in patristic authors in connection with God calling back man, e.g. Ps.-Chry-

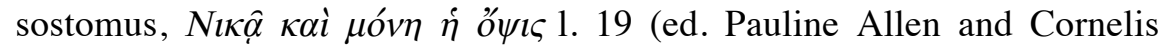
Datema, "Text and Tradition of Two Easter Homilies of Ps.Chrysostom," Jahrbuch der Österreichischen Byzantinistik 30 [1981]: 99). The argument of Jesus' coming to recall the fallen man is a frequent topic in the 
Post-Sanctus parts of the anaphoras of Syrian type, see Budde, Die ägyptische Basilios-Anaphora, 274.

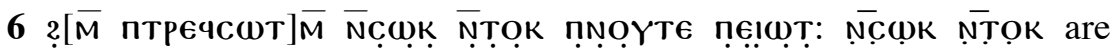
discernible if the two parts of the broken papyrus are juxtaposed correctly but this cannot be done physically as the two halves of the sheet have suffered different degree of shrinkage.

This is the first of a series of parallel constructions consisting of a prepositional construction with $2 \overline{\mathrm{M}}$ that governs a substantivized inflected infinitive which is followed by verbs in the perfect tense, used to narrate the salient points in Jesus' life (11. 6-7, 7-9, 10-12).

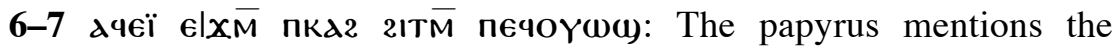
willingness of Christ twice, the first one here in connection with the incarnation, and the other one in 1.9 in connection with his suffering.

The emphasis on Christ's willingness - and implicitly on his sharing of and obedience to the Father's will - is probably based primarily on the general description of the unity between the Father and the Son in the New Testament, particularly its portrayal in the priestly prayer of Jesus in

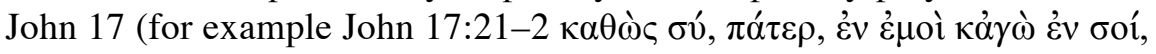

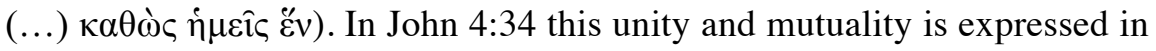
terms of volition "my food is to do the will of him who sent me" (દ) $\mu$ òv

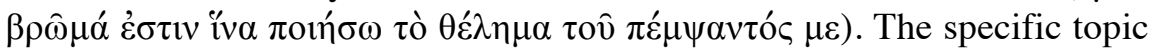
of Jesus being willing to become a human being is not found explicitly in the New Testament, but may be seen as an elaboration on the image of Christ given in the Carmen Christi of Phil 2:6-11. Here the pre-existent Son is said to have become a human being by having "emptied himself

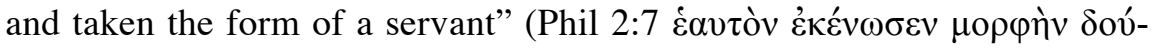
$\lambda$ ov $\lambda \alpha \beta \omega ́ v)$ even though he originally "was in the form of God" (Phil 2:6

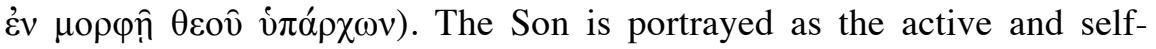
determining subject of this change of status, thereby indicating that the incarnation came about as a result of his own will.

The weight on the will of Jesus and the Father in connection with the incarnation is also attested in the Post-Sanctus of the anaphora of Severus of Antioch, see Anaphorae Syriacae quotquot in codicibus adhuc repertae sunt (Roma: Pontificium Institutum Orientalium Studiorum, 1939), vol. $1.1,67$. 
7 The reconstruction $\lambda \gamma \omega 2 \bar{M}$ [nTpeqXICAP] . can be proposed since the text here follows the sequence "took flesh (from the Holy Spirit and the Virgin Mary) - became man" of the Nicene-Constantinopolitan Creed, as do the short versions of Jesus' life contained in the aspasmos prayer and in the final inclination of the liturgy of St. Gregory (see Ernst Hammerschmidt, Die Koptische Gregoriosanaphora: Syrische und griechische Einflüsse auf eine Ägyptische Liturgie [Berlin: Akademie Verlag, 1957], 12-17 and 74-7), as well as in the fraction prayer of Severus of Antioch in the Great Euchologium (Lanne, Le Grand Euchologe, 370). Similar constructions are attested in the fraction prayer of the liturgy of St. Gregory EвО入 2ITEN nEkXINGicapz (Hammerschmidt, Die Koptische Gregoriosanaphora, 66 1. 339), and in an aspasmos prayer from the euchologium MONB.VF of the White Monastery Leiden, RMO Copte 71 (Insinger 28) 11. 5-6 $2 \overline{\mathrm{N}}$ TEqloinxicapz. (W. Pleyte and P.A.A. Boeser, Manuscrits coptes du Musée d'antiquités des Pays-Bas à Leide [Leiden: Brill, 1897],

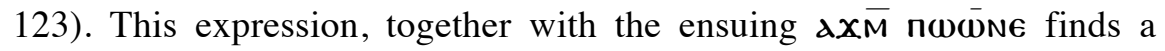
parallel in the consecratory prayer of the rite of the filling of the chalice

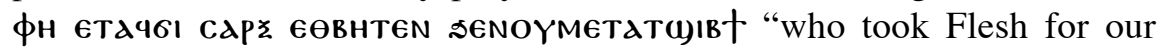
sake, without corruption" (Habīb Al-Mașrī, "The Rite of the Filling," 81).

$\operatorname{ax\overline {M}} \Pi \omega \bar{\omega}$ Ne: The fraction prayer attributed to Severus of Antioch in

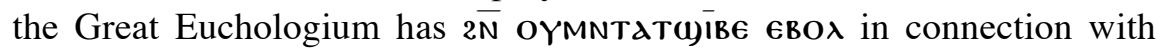
the incarnation; see Lanne, Le Grand Euchologe, 370. The Greek version of the same prayer is in the liturgy of St. Gregory in Paris, BnF Gr. 325 (Eusèbe Renaudot, Liturgiarum Orientalium Collectio [Paris: J.B. Coignard, 1716], 114-116), and while it does not have the equivalent ex-

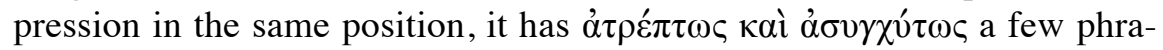
ses later in a theological exposition of the two hypostaseis of Jesus, which is shortened in the Sahidic redaction where the two adverbs are left out. A very similar expression qualifies the incarnation in the aspasmos prayer of

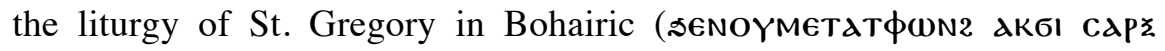
"without change he took flesh," Hammerschmidt, Die Koptische Gregoriosanaphora, 141.15 ). A series of statements about the indivisible nature of Christ are found also in the confession of the people before communion, which has the same form in the three Bohairic liturgies, and contains the following three words sENOYMETATMOYXT NEM OYMETATEWన NEM oүmєTdT()ıв† "without mixing, without being mixed, and without change" (Hammerschmidt, Die Koptische Gregoriosanaphora, 70 1. 367). 
According to Athanasius, Arius had claimed that the Son of God (the Logos) was "not incapable of a change ( $\alpha$ ' $\rho \varepsilon \pi \tau o \varsigma)$, like the Father, but $\mathrm{He}$

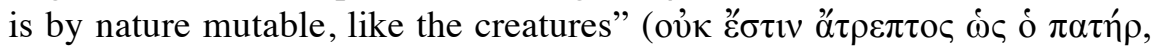

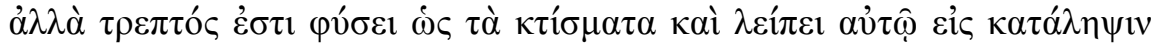

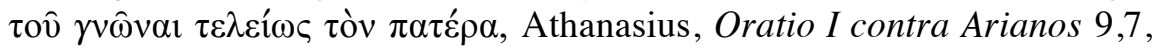
ed. Karin Metzler and Kyriakos Savvidis, Athanasius: Werke, Band I: Die dogmatischen Schriften, Erster Teil, 2. Lieferung: Orationes I et II contra Arianos [Berlin and New York: De Gruyter, 1998], 118.21-22). The point of Arius was mainly in reference to the moral aspects of the Son. In his view the Son could have decided to act counter to the will of the Father just as other creatures, but he decided by the power of his will not to do so, thereby remaining sinless in all his actions. This Arian view of the inferiority of the Son compared to the Father, and his placement in the sphere of the created substances was condemned in the anathemas appended to the Nicene Creed of 325 . The theme of unchangeableness re-occurs in the following centuries when the dispute moved more towards a purely Christological argument (the relationship between the two natures in Christ) rather than a Trinitarian one (the relationship between the Father and the Son). For example in the sixth ecumenical council in Constantinople in 680-681 which dealt with the Monothelite conflict, the two natures of Christ and, in conjunction with this, the two wills or volitions of

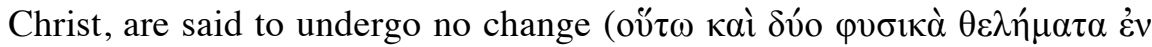

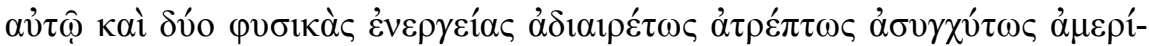
$\sigma \tau \omega \varsigma \pi \rho \varepsilon \sigma \beta \varepsilon v \dot{o} \mu \varepsilon v$, Concilium universale Constantinopolitanum tertium (680-681) 22 [ACO Series secunda, 2,2, 890,10-11 Riedinger]; see also Jaroslav Pelikan and Valerie R. Hotchkiss, Creeds and Confessions of Faith in the Christian Tradition [New Haven and London: Yale University Press, 2003], vol. 1, 225). The perfect union of the two natures of Christ without change into an indivisible single nature was one of the cardinal points of Cyril of Alexandria's theology, which was taken up and elaborated upon by Severus of Antioch as well (Davis, Coptic Christology in Practice, 50-52).

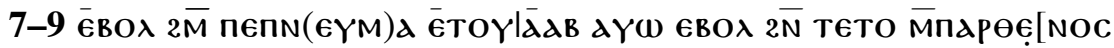

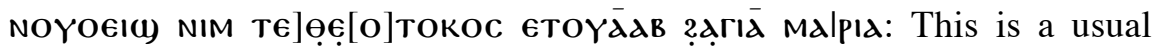
statement in the creeds. In the Sahidic Nicene-Constantinopolitan Creed it

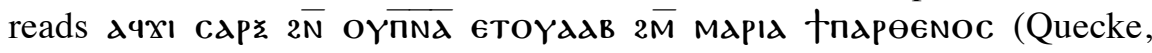
Untersuchungen, 436 11. 20-22). 
Teto Mnapeenoc NoYoeic) NIM is one of the Sahidic translations of the Greek adjective $\dot{\alpha} \varepsilon ı \pi \alpha \dot{\alpha} \theta \varepsilon v o c$, e.g. in the Sahidic translation of the anaphora of St. Mark/Cyril in the Great Euchologium, p. 39.15-17 (Lanne, Le Grand Euchologe, 292). Another possibility is TnapeenOc Noyoeıa) NIM, as e.g. in Louvain, ms. Lefort s.n. fol. 6r.16-v.1, see Jean Doresse and Emmanuel Lanne, Un témoin archä̈que de la liturgie copte de S. Basile (Louvain: Université catholique de Louvain, Institut orientaliste, 1960), 26.

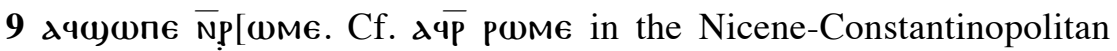
Creed (Quecke, Untersuchungen, 436 1. 22). This translation of the Greek $\dot{\varepsilon} \vee \alpha v \theta \rho \omega \pi \eta$ ́ $\sigma \alpha \varsigma$ is also attested in the first aspasmos prayer of the Bohairic liturgy of St. Gregory (Hammerschmidt, Die Koptische Gregoriosanaphora, 14 11.15-16; see also Renaudot, Liturgiarum Orientalium, 96).

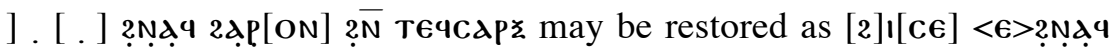
$2 \alpha p[O N] 2 \frac{\bar{N}}{T E 4 C A p z}$ in the light of the Sahidic redaction of the final inclination prayer of the liturgy of St. Gregory preserved in the White Monastery euchologium MONB.VF on BnF, Copte $129^{20}$ fol. 138r.4-5

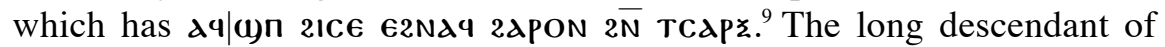
what is probably an $\mathrm{I}$ is visible above the staurogram, so that there would not be enough space for $\mathbf{\epsilon} \epsilon$. An $\epsilon$ may have been dropped due to haplography.

The willingness of Christ to undergo suffering again finds a New Testament basis in the Carmen Christi of Phil 2:6-11, where in v. 8 the preexistent and now incarnate Son is said to have "humbled himself and

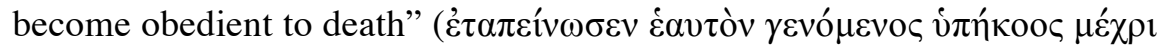

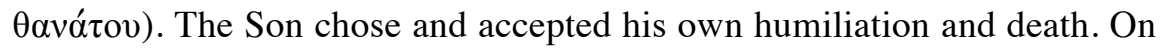
the other hand, Jesus' attitude of accepting death is somewhat differently portrayed in parts of the synoptic tradition. In Mark 14:36 (// Matt 26:39) Jesus in Gethsemane is described as praying to the Father for the possibi-

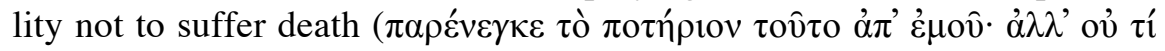

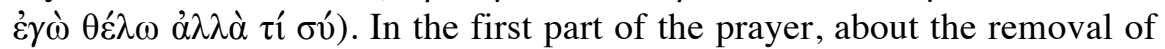
the cup, Jesus seems to want something else than the Father, while in the second part he yields to the paternal plan. This image of Jesus became a

\footnotetext{
${ }^{9}<$ http://gallica.bnf.fr/ark:/12148/btv1b525015068/f54.image> (last accessed 12/01/ 2016).
} 
source of embarrassment to some of the church fathers ${ }^{10}$ and gave rise to debates whether the will of the Son and the will of Father were not one or in unison.

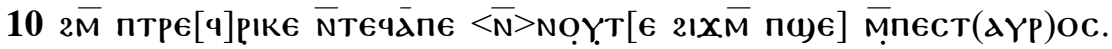
Cf. John 19:30c дqpike NTE4ane and the final inclination prayer in the White Monastery Great Euchologium, p. 216.28-9: ксмдмddт eкNapïке

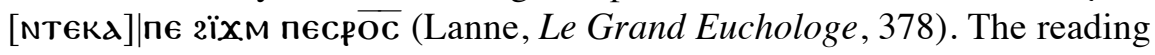
$\langle\bar{N}>$ NOYT $[\epsilon$ is uncertain. If admissible, it involves a haplography. It is supported by the qualification of Jesus' hands and feet in the Great Euchologium as "divine," p. 216.26-27: nEOOY NAK EYEЧT EIYT [NNEK-] GIX MN NEKOYEPHTE NNOYT[E]. If the reading is correct, it once more echoes Cyril's theology of the prefect and indivisible unity of the divine and the human nature of Christ through suggesting that Jesus died on the cross in his divinity as well as in his humanity.

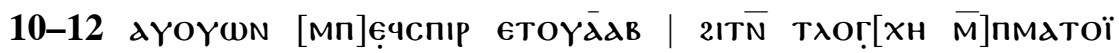

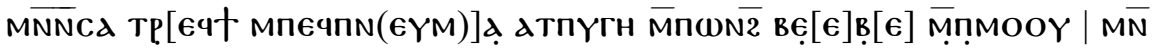
neçọ. Compare John 19:34. The consecratory prayer of the rite of the

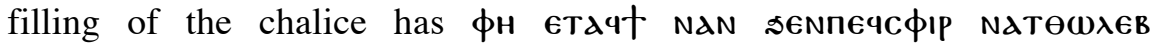
NOYMOYMI NTE חWNฎ ("he who gave us from his immaculate side a source of life," Habīb Al-Mașrī, "The Rite of the Filling," 81). The image of blood and water flowing from Jesus' side are particularly appropriate to a consecration prayer of the cup as it was interpreted as a prefiguration of the Eucharist already by ancient commentators, see e.g. Ambrosius, De Virginibus 3,5,22 (FC, 81,308 Dückers); Augustinus, Ennarratio in Psalmum 65,7 (PL, 36,793 Migne) and Ennarratio in Psalmum 127,11 (PL, 37, 1684 Migne), and Theodoretus, Eranistes Dial. 1 (ed. Gérard H. Ettlinger, Theodoret of Cyrus: Eranistes [Oxford: Clarendon Press, 1975], 77-8).

11 The supplement in the second lacuna is based on John 19:30d dat mnEnNd, which also in the Gospel follows the bending of the head. nNEYMd is abbreviated, as expected (cf. 1. 3). Traces of the supralinear stroke above the $\boldsymbol{d}$ are just about visible. The supplement is also supported

${ }^{10}$ E.g. Origenes, Exhoratio ad martyrium 29 [GCS 2, 25,3-26,19 Koetschau]; Johannes Chrysostomus, Homilia in Matthaeum 83,1 (on Matt 26:36-8) [PG, 58, 745,27-746,44 Migne] and Homilia in Joannem 67,1-2 (on John 12:25-26) [PG, 59, 371,29-372,6 Migne]). See Karl O. Sandnes, Early Christian Discourses on Jesus' Prayer at Gethsemane. Courageous, Committed, Cowardly? (Leiden and Boston: Brill) 2016. 
by a parallel in the first fraction prayer of the liturgy of St. Gregory: $\phi \lambda$ I

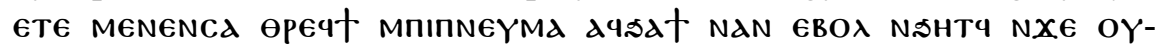
MWOY NEM OYCNO4 "he who after he gave his spirit, water and blood flowed from him for us" (Hammerschmidt, Die Koptische Gregoriosanaphora, 66 1. 341). A similar theme is found in the anaphora of the Arabic redaction of the Testamentum Domini (see Anton Baumstark, "Eine ägyptische Mess- und Taufliturgie vermutlich des 6. Jahrhunderts", Oriens Christianus 1 (1901): 13) nobis regenerationem largitus sit per aquam puram et salutem nobis dederit per sanguinem suum vivificantem, qui in crucem ex latere eius profluxerunt, postquam spiritum suum tradidit.

13-14 ETPEKTNOOY NAN TENOY M̄TEKחN(EYM)d [ETOYĀab aY]

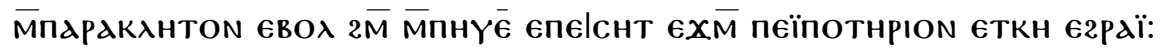
Typical wording of the epiclesis. A rather close parallel can be found in

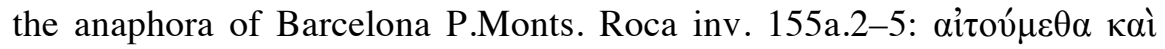

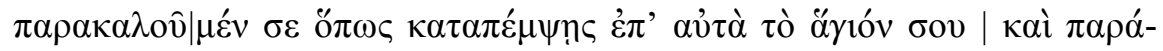

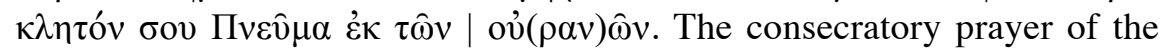
rite of the filling of the chalice, as well as those of the Syrian presanctified of Severus of Antioch (see H.W. Codrington, "The Syrian Liturgies of the Presanctified," Journal of Theological Studies 4 [1903]: 75) and of John Chrysostom (see H.W. Codrington, "Liturgica Praesanctificatorum Syriaca S. Ioannis Chrysostomi," X Giovanni Crisostomo [Roma: Libreria Pustet, 1908], 725-726) do not contain any explicit epiclesis of the Holy Spirit; the last one refers in passing to the "operation of the Holy Spirit". The consecratory prayer of the Nubian presanctified on the other hand contains an explicit epiclesis: "send down the power of the Holy Spirit on the mixture which is in this cup" (Alexopoulos, The Presanctified Liturgy, 116).

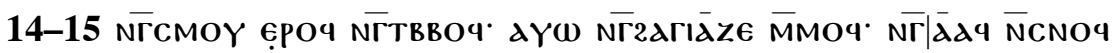

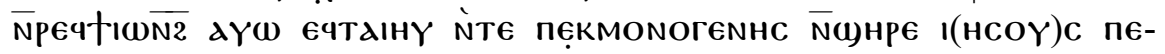
$x$ (PICTO)C neNXoeIC: The subjunctives have been corrected from the third to the second person, the confusion being between the Holy Spirit who is the closest referent and the correct agent of the verbal action, the Father. In the scholarship on the epiclesis-prayer of the early Egyptian church there has been a debate on who was originally the referent of this prayer and thereby the effector of the transformation of the bread and wine into the body and blood of Christ. In the Euchologium of Sarapion of 
Thmuis (prayer 1), dated in the middle of the fourth century, ${ }^{11}$ it is the Logos - the second member of the Trinity - that is portrayed as being sent from God and consecrating the elements, while for example in Peter II, patriarch of Alexandria 373-380, an invocation of the Spirit seems to be presupposed. ${ }^{12}$ With both of these two options God the Father would be seen as the sender and intimately participating in the Eucharistic actions. The verbal corrections in P.Oslo inv. 1665 from third person (the Spirit) to second person (the Father) do not seem to be a part of this theological fluidity between the Son and the Spirit, and should probably be seen as a mere scribal error. Having first directed his prayer to God the Father (in second person verbs) for sending the Spirit, and adding a few words specifying whence and whither this Spirit should descend (in third person verbs), he then went on to describe (still in third person verbs) the anticipated effects of this sending (the transformation of the elements), and only when he reached the second person possessive marker in the phrase "the life-giving and honoured blood of your only-begotten son" (1. 15 nєкMоNorenнc) did the scribe realize his mistake and went back and changed the prior verbs so that they referred to the Father and not to the Spirit.

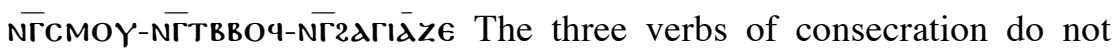
find an exact parallel, but they come close to the triad of the anaphora of St. Mark in the Vat. Gr. 2281 (see Geoffrey J. Cuming, The Liturgy of St. Mark [Rome: Pontificium Institutum Studiorum Orientalium, 1990], 46)

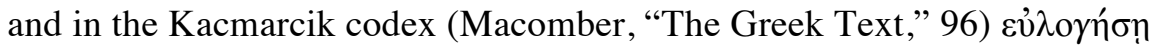

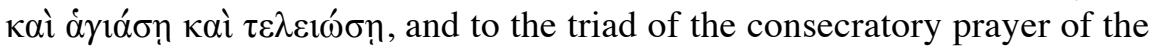

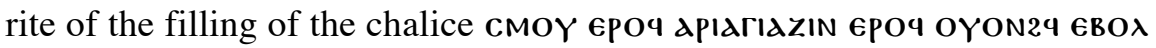
NOYCNOY EqOYAdB "bless it, sanctify it and manifest it as a holy blood" (Habīb Al-Mașrī, "The Rite of the Filling," 81).

${ }^{11}$ This represents the traditional dating of the text. This dating has been contested, with some regarding it as a product of the fifth century after the pneumatological disputes of the second half of the fourth century, but the pendulum seems to have swung back to the traditional dating. For this and a discussion of the Logos or Spirit epiclesis see Maxwell E. Johnson, "The Archaic Nature of the Sanctus, Institution Narrative, and Epiclesis of the Logos in the Anaphora Ascribed to Sarapion of Thumis," in Essays on Early Eucharistic Prayers (ed. Peter F. Bradshaw; Collegeville, Min.: The Liturgical Press, 1997), 73-107.

${ }^{12}$ See Theodoretus Historia Ecclesiastica 4:19 (GCS 19, 251, 11-18 Parmentier). According to Johnson this "invocation of the Holy Spirit in the eucharist is the first such explicit reference to be found anywhere in the Egyptian tradition" (Johnson, "The Archaic Nature," 97). 


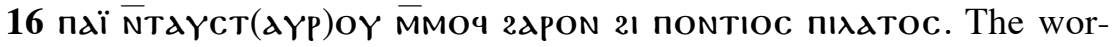
ding coincides with that of the Nicene-Constantinopolitan Creed (Quecke, Untersuchungen, 436).

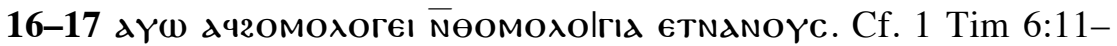

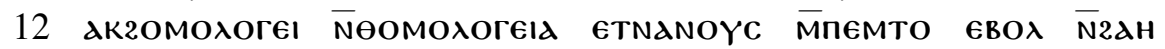

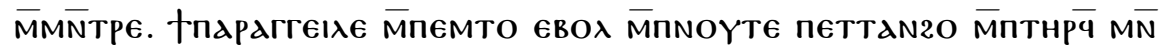

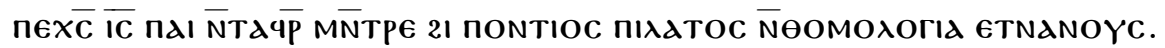
The phrase is part of the confession of faith before the communion, which is common to the three liturgies of the Coptic Church (Hammerschmidt, Die koptische Gregoriosanaphora, 70 1. 368; The Coptic Liturgy, 274 and Frank E. Brightman, Eastern Liturgies: Being the Texts Original or Translated of the Principal Liturgies of the Church [Piscataway NJ: Gorgias Press, 1896/2002], 185). The confession of faith was part of the Egyptian liturgy since the fifth century, see Heinzgerd Brakmann, "Le déroulement de la messe copte: Structure et histoire," in L'eucharistie: célébrations, rites, piétés (ed. A.M. Triacca and A. Pistoia; Roma: C.L.V. Edizioni liturgiche, 1995), 128, although probably not with the same wording.

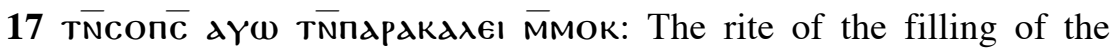
chalice joins the epiclesis to the request for the fruits of communion more smOothly by 2INA OYON NIBEN EONAGI EBO $\lambda$ MMOY NTOYTOYBO "in order that all who shall partake of It may be purified" (Habīb Al-Mașrī, "The Rite of the Filling," 81). Similar connection between the epiclesis and the requests for the fruits of communion is made in several anaphoras, e.g. Mark (Cuming, The Liturgy, 48), James (Brightman, Eastern Liturgies, 54), Chrysostom (Brightman, Eastern Liturgies, 331), as well as in the consecration prayer of the Syrian presanctified of John Chrysostom (Codrington, "Liturgica Praesanctificatorum Syriaca," 726) and of Severus of Antioch (Codrington, "The Syrian Liturgies," 75).

The arrangement that the scribe left half a line empty at the end of 1.15 was probably intended to make the use of the leaf during the recitation of the liturgy easier, as this way the celebrant can turn the leaf over while pronouncing a well-known formula.

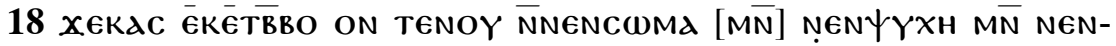
$\Pi N(G Y M) d$ : This comes close to the wording of the consecratory prayer of the rite of the filling of the chalice, NTOYTOYBO senTOY $\psi$ YXH NEM nOYCWMA NEM nOYחNd "in their souls, and their bodies, and their spirits" (Habīb Al-Mașrī, "The Rite of the Filling," 81) but similar phrases are 


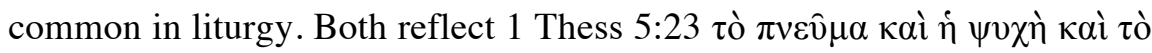
$\sigma \hat{\omega} \mu \alpha$, although in reverse order. The order represented by the prayer for the filling of the chalice is in agreement with the usual order of the phrase in Egyptian liturgical texts, for a survey see Frank E. Brightman, "Soul, Body, Spirit," Journal of Theological Studies 2 (1901): 273-274.

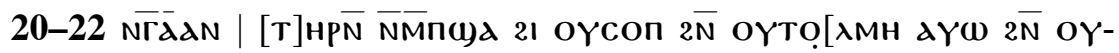

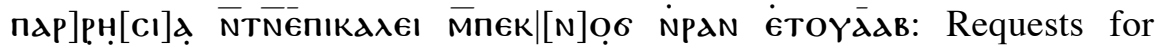
worthy recitation of the Lord's Prayer usually serve as introductions to it in fraction prayers, and have various forms. In $1.212 \bar{N}$ оүто्] $[\lambda M H$ is conjectured since the verbal form of the word is frequent in the final phrases

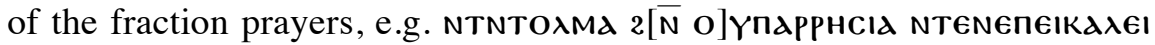
$\mathrm{M}[\mathrm{MOK}]$ "so that we dare call upon you openly" (P.Lond. Copt. I $152 \beta$ ). However, here a noun is necessary, and we may assume that a variant of this expression with the noun form was used instead. The second noun, of which only the last letter can be seen with confidence, is customary and present in almost all introductory phrases to the Lord's Prayer.

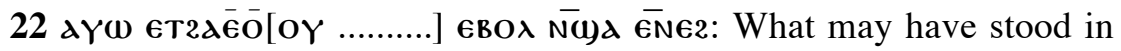
the lacuna is another attribute to God's name or a prepositional phrase

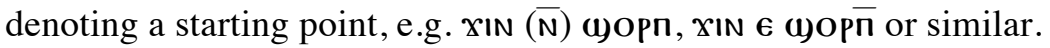

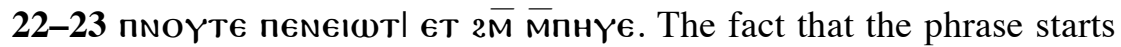
with nNOYTe implies that this is not part of the ensuing Lord's Prayer which is anyway regularly introduced by $\mathbf{E N X \omega ~ M M O C ~} \boldsymbol{\top} \epsilon$ or similar, but a realization of the situation envisaged in 11. 21-2, i.e. mentioning God's name and an address to God.

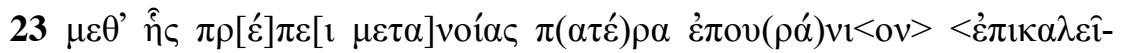

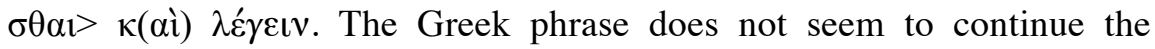
Coptic text. It is somewhat garbled as it lacks the infinitive which is the counterpart of $\lambda \dot{\varepsilon} \gamma \varepsilon ı v$ (probably $\dot{\varepsilon} \pi \kappa \alpha \lambda \varepsilon \hat{\imath} \sigma \theta \alpha \imath$ ). In terms of content it repeats the invocation of God as heavenly father and functions as a preface to the ensuing recitation of the Lord's Prayer. While the Coptic Church kept many sentences in Greek, especially acclamations of the people and the dialogue of the priest and the deacons with the people (Budde, Die ägyptische Basilios-Anaphora, 597-8), such an instance of bilingualism within one prayer, and, if it is intended as the continuation of the previous phrase, in the same structure, is unique. In a liturgical setting it is conceivable that the Greek coda alerted the faithful that their turn was approaching. 


\section{Translation}

(Front) Lord, Lord, God Almighty, the Father of our Lord and Saviour, Jesus Christ, we pray I and beseech you, the Lover of Man, over this sacrament which is put forth. It is this that has been purified I and already sanctified through the pouring over it of your Holy Spirit, I the life-giving and co-substantial w[ith] you (?) and [your] beloved(?) son, Jesus Christ, our Lord, the $\mathrm{I}^{5}$ one begotten of you ... [...] the world out of your breast so that he would I recall man who had fallen; and in [obeying] you, God the Father, he came I to the earth willingly, and [in taking flesh] without corruption from the Holy Spirit I and the [ever-]virgin [holy mother of God], the holy Mary, I he became man [...], suffered willingly in his flesh $I^{10}$ and, as he inclined his god(?)-head [on the wood] of the cross, his holy side was pierced open I by the spear of the soldier, after [he gave up his spirit,] the spring of life poured forth for us(?) the water I and the blood. Therefore(?) we pray and [beseech you], holy and man-loving Father, I to send us now your Holy Spirit, the Advocate, from heavens down I upon this chalice which is put forth; so that you may bless it, purify it, hallow it, $\mathrm{I}^{15}$ make it the life-giving and honoured blood of your only-begotten son, Jesus Christ, our Lord, I he who was crucified for us under Pontius Pilatus and professed the faith I which is good. We pray and beseech you

(Back) so that now again you may purify our bodies and souls and spirits before I we receive to us your holy and glorious sacraments and grant us all means $I^{20}$ to advance with confidence and receive (of) them in gratitude; and make us all together worthy to dare with confidence to invoke your I great name, which is holy and glorious [...] to eternity, God, our heavenly Father: I (in Greek) <to invoke?> the heavenly father in the due sense of repentance and say ...

\section{Liturgical Commentary}

The task of a detailed liturgical assessment of the prayer is best left to the scholars who specialize in the study of early Christian liturgy. Suffice it here to point out some possible connections in order to orient the reader of this edition.

The reference to the "already sanctified mystery" (1. 2) implies a relationship to the liturgy of the presanctified. This rite involves the consecra- 
tion of the chalice through signing it with the already consecrated bread, reserved from a previous Eucharist, on a day when the mass is not celebrated but communion is administered. Since communion necessitated wine, but consecrated wine could not be kept overnight for fear an accident might happen to it, the liturgy of the presanctified was introduced to cover for the need of subsequent consecration of wine only. For a detailed discussion of this service see Alexopoulos, The Presanctified Liturgy. The liturgy of the presanctified is still celebrated in the Byzantine rite and is also known from the West and East Syrian rites. Some scattered evidence suggests moreover that the Egyptian rite once had a presanctified as well (Alexopoulos, The Presanctified Liturgy, 113-117). To this a story from The History of the Patriarchs of the Egyptian Church (ed. Aziz Suryal Atiya, Yassa 'Abd al-Masih, and O.H.E. Burmester, [Cairo: Publications de la Société d'archéologie copte, 1959], vol. II pt. 3, 262) can be added, which reports the custom of the reservation of the Eucharist from Palm Sunday to the first three days of the Holy Week in the Monastery of St. Macarius and in the churches of Alexandria, abolished by the patriarch Christodoulus (1047-1077).The prayer of P.Oslo inv. 1665 may be interpreted as another witness to the presanctified in Egypt.

However, there is yet another possibility. The wording and the structure of the prayer on P.Oslo inv. 1665 finds a striking parallel in the consecratory prayer of the rite of the filling of the chalice. This was first printed in

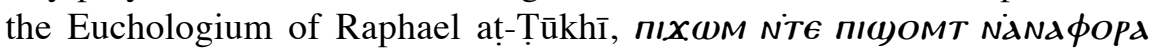
(Book of the Three Anaphoras) (Roma, 1736), fol. TNB-TOd. It was then edited from two codices by İris Habīb Al-Mașrī (Habīb Al-Mașrī, "The Rite of the Filling"), and it was described in Oswald H.E. KHS-Burmester, The Egyptian or Coptic Church. A Detailed Description of Her Liturgical Services and the Rites and Ceremonies observed in the Administration of her Sacraments (Cairo: Publications de la Société d'archéologie copte, 1967), 88-90. The rite is supposed to be celebrated above the chalice if at the point of the communion the wine is found to be missing, or turned sour, or contaminated. It is first attested in the liturgical commentary of Ibn Kabar (thirteenth/fourteenth cent., see Habīb AlMașrī, "The Rite of the Filling," 78). It gives the same incipit for the consecratory prayer as the one printed by TTūkhī (Habīb Al-Mașrī, "The Rite of the Filling," 88). During the rite, a consecratory prayer is pronounced over the chalice, which leads on to the Lord's Prayer. It reads as follows:

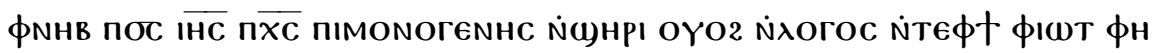
ETAYGICAPZ EӨBHTEN DENOYMETAT()IB† ETAYGIMKA2 DENTEYOYW() 


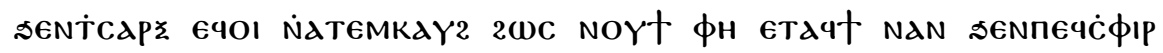

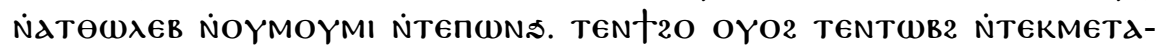

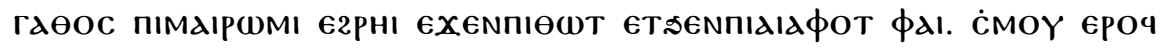

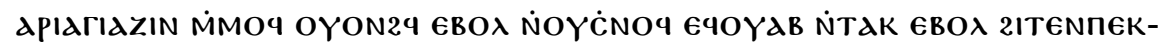

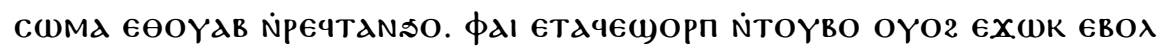
2OחWC NTEYEPOYAI NEMAY IINA OYON NIBEN EONAGI EBO $\lambda$ MMOY NंTOY-

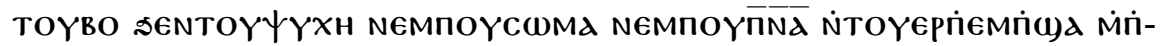

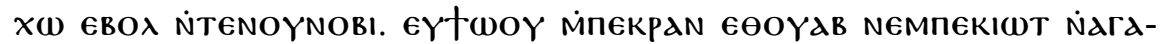

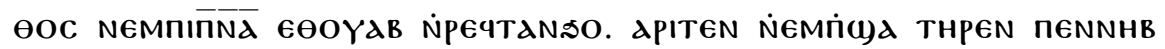

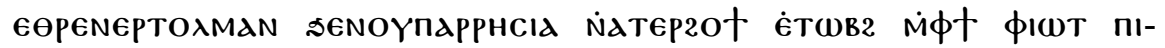
חANTOKPATWP इENNIQHOYI OYO2 EXOC XEחENIWT ET DENNIQHOYI

"Master, Lord Jesus Christ, the Only-Begotten Son and Word of the Father, who took Flesh for our sake, without corruption, who accepted suffering in the flesh of His own will, being impassible as God; who hath given to us from His immaculate side a spring of life. We beseech and pray Thy Goodness, Lover of Man, for the mixture which is in this Chalice. Bless it, sanctify it, manifest it as Thy Holy Blood, through Thy Holy Life-giving Body. Which is already sanctified and perfected, so that It may be one with It, in order that all who shall partake of It may be purified in their souls, and their bodies, and their spirits, (and) may be made worthy of the forgiveness of their sins, (and) may glorify Thy Holy Name with Thy Good Father, and the Holy Life-giving Spirit. Make us all worthy, our Master, to dare with confidence, (and) without fear to pray to God the Father Almighty (who is) in the Heavens, and to say: 'Our Father who (art) in the Heavens', etc." (Habīb Al-Mașrī, "The Rite of the Filling," 82-83 and 87).

This prayer exhibits many similarities in structure, expressions and topics to our prayer. Both contain a short version of the life of Jesus, with reference to his sufferings by his own will, and in particular to the source of life that came forth from his opened side. Then both move on to a request to the addressee of the prayer to bless the chalice, and finish with a list of the effects of communion, which terminates in the Our Father. This last point is particularly significant, as we know of no other prayers which combine a consecratory element directly with the Lord's Prayer. Common is moreover the phrase "which is already sanctified" with reference to the bread. However, there are some major differences as well. Our prayer is directed to the Father, even though a large part of it focuses on the Son, and requests the coming of the Holy Spirit on the chalice, without a refe- 
rence to the physical contact between the body and the blood (which of course could happen without a mention in the text). In fact, the text may be considered as a variant of the consecratory prayer of the rite of the filling of the chalice, directed to the Father instead of the Son, filled with a longer version of Jesus' life, and brought in line with the theology of the Eucharist through the inclusion of an epiclesis of the Holy Spirit (just as Țükhī, member of the United Coptic Church brought his version of the filling of the chalice in line with the Catholic theology of the Eucharist by placing the institution narrative of the chalice and an epiclesis before it, see Habīb Al-Mașrī, "The Rite of the Filling," 78). However, this parallel does not necessitate that our prayer was used precisely in the rite of the filling of the chalice.

One more related practice can be drawn into the discussion. In 2012 Alberto Camplani edited a pastoral epistle, P.Berol. 11346 (seventh cent., Thebaid), in which instructions are provided in the event that the priest does not have enough consecrated bread for the communion and needs to introduce some after the anaphora. According to it after the priest has performed the manual acts, he should call out to the people: $1 . x+27 \mathrm{Td}$ npoariace€nTd $\{T \lambda\}$ arid TOIC driOIC "the presanctified holies to the holies". A similar rite is mentioned in the Sahidic redaction of the Canons of Basil, Canon 99. According to the text of a recently discovered manuscript in the rubbish dump of a Western Theban hermitage MMA 1152, in case the amount of bread and wine does not suffice for the communicants, the priest can consecrate additional bread and wine by bringing it in contact with the already consecrated element. The two testimonies suggest that in the Thebaid in the seventh century a practice of consecrating additional bread and wine after the anaphora was known. A similar practice was recorded centuries later by the liturgical commentator Ibn Siba (thirteenth century, Vincentius Mistrîh, Jûhannâ ibn Abî Zakarîâ ibn Sibâ', Pretiosa margarita de scientiis ecclesiasticis. [Cairo: Centrum Franciscanum Studiorum Orientalium Christianorum, 1966], 538-539). His description concerns only additional wine introduced at the point of the communion because of the multitude of communicants. The new chalice could be consecrated through an exchange of wine between the already consecrated chalice and the additional one, accompanied by the

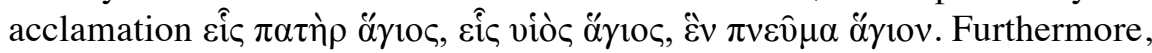


pieces of the already consecrated bread are dropped in the new chalice. ${ }^{13}$ None of the three descriptions of this practice refer to prayers. However, this does not exclude that the prayer on P.Oslo inv. 1665 belonged to a similar rite. The fact that only this practice is attested in the period to which our papyrus is dated may weigh in favour of this interpretation.

This having been said, there are no definitive arguments for any of these three options. The lack of instructions in P.Oslo inv. 1665 makes it impossible to decide whether the prayer belonged to a liturgy of the presanctified, to an early version of the rite of the filling of the chalice, or to a service to consecrate additional wine in case of shortage during communion. At the same time, it is evident that these three practices are closely interconnected. The rite of the filling of the chalice and the service described by Ibn Siba both serve to consecrate extra wine in case it is found lacking at the point of the communion for some reasons. The service of

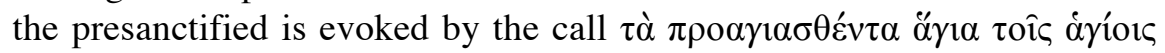
in P.Berol. 11346. $x+27$. Therefore, these three practices may effectively be seen as variations on a theme, the consecration of additional wine and occasionally bread without the recitation of an anaphora but in the presence of already consecrated elements. Only the reasons that necessitate it vary: communion without a Eucharistic service and the ban on the reservation of wine in the case of the presanctified, an accident in the case of the rite of the filling of the chalice, or the multitude of people in the third case. The prayer on P.Oslo inv. 1665 could be used for any of these needs, and indeed potentially for multiple needs as the practice of the local community required it.

${ }^{13}$ The Canonical Answers of Timothy of Alexandria, answer XXIV, discusses a related practice. The question relates to the possibility of consecrating additional wine if new communicants arrive after the communion and the consumption of the leftovers by the priests. The answer permits the consecration of wine after the anaphora in such cases but does not discuss how the priest should do it (Périclès-Pierre Joannou, Discipline générale antique. T. II. Les canons des Pères Grecs [Rome: Tipografia Italo-Orientale «S. Nilo», 1963], 255). The attribution of the answer, which is transmitted in Byzantine canonical collections, to Timothy I is uncertain (Joannou, Discipline générale antique, 239), thus it is questionable whether it describes a fourth-century Egyptian custom. 